\title{
A Critical Evaluation of Water Coning Correlations in Vertical Wells
}

\author{
Anietie Ndarake Okon ${ }^{1, *}$, Dulu Appah ${ }^{2}$, Julius Udo Akpabio ${ }^{1}$ \\ ${ }^{1}$ Department of Chemical and Petroleum Engineering, University of Uyo, Uyo, Nigeria \\ ${ }^{2}$ Department of Gas Engineering, University of Port Harcourt, Port Harcourt, Nigeria \\ Email address: \\ anietieokon@uniuyo.edu.ng (A. N. Okon) \\ ${ }^{*}$ Corresponding author
}

\section{To cite this article:}

Anietie Ndarake Okon, Dulu Appah, Julius Udo Akpabio. A Critical Evaluation of Water Coning Correlations in Vertical Wells. American Journal of Science, Engineering and Technology. Vol. 3, No. 1, 2018, pp. 1-9. doi: 10.11648/j.ajset.20180301.11

Received: December 17, 2017; Accepted: January 3, 2018; Published: January 19, 2018

\begin{abstract}
In oil and gas production, developing bottom-water reservoirs with active aquifer requires production strategy that can handle production-rate-sensitive phenomenon - water coning. The coned water that moves into the completion interval results in production related problems: excessive water production, surface water handling, low oil productivity, among others. To this end, several correlations: critical rate, breakthrough time and water-cut performance after breakthrough have been developed based on analytical, empirical and numerical approach to evaluate water coning tendencies in petroleum reservoirs. Some of the developed correlations have gained field application. However, limited literatures are available that have evaluated the prediction of these water coning correlations. Thus, the various water coning correlations for vertical well were evaluated and the obtained results show that most correlations have the same prediction profile. Conversely, these correlations predicted different coning parameters' value. Further analysis of the results depicts that critical production rate and breakthrough time in vertical wells are indirectly dependent on fractional well penetration. In addition, the correlations developed from water-cut data for the prediction of water-cut performance after breakthrough indicate more realistic predictions in the water-cut profile than the correlations developed from water-oil ratio. Therefore, to delay water coning tendency in bottom-water reservoirs, fractional well penetration is a consideration in vertical wells to establish optimum critical oil rate and breakthrough time during oil and gas production.
\end{abstract}

Keywords: Bottom-Water Reservoirs, Water Coning Correlations, Critical Rate, Breakthrough Time, Water-Cut Performance, Vertical Well

\section{Introduction}

In the petroleum industry, one of the major problem associated with the production of hydrocarbons, is the production of water; especially when the reservoir is supported by active bottom-water. The water production may come in the form of a tongue, cone, cusp or a combination of all depending on the location, magnitude and direction of water movement [1]. In strong bottom-water drive reservoirs, oil production from well (s) in these reservoirs lead to changing pressure drawdown around the wellbore, which causes the movement of oil-water interface toward the producing interval. Thus, the fluid interface deforms from its initial shape into a cone shape and results in a production related phenomenon referred to as coning. Generally, coning is the term used to describe the mechanism underlying the upward movement of water and/or the downward movement of gas into the perforations of a producing well [2]. This production rate-sensitive phenomenon has been a major challenge in the oil and gas industry, as it occurs when there is an imbalance of forces between viscous and gravity forces [3]. Azim [4] maintained that there are essentially three forces, namely, capillary, gravity and viscous, controlling the mechanism of water coning. In bottom-water drive reservoir, during oil production, the pressure drop in the wellbore tends to draw-up water from the water zone towards the lowest producing interval at the well. This phenomenon may result in water breaking (i.e., breakthrough) into the perforation intervals, if not curtailed. Hatzignatiou and Mohamed [5] opined that the tendency of coning is inversely proportional 
to fluid viscosity and reservoir permeability, and directly proportional to the density difference between reservoir fluids. The study of water coning cannot be overemphasized, as several correlations have been developed to predict this production rate-related problem. The focus of coning prediction correlations have been on critical rate, breakthrough time and water-cut (or water-oil ratio) performance after breakthrough based on two approaches: analytical and empirical. Among these correlations, critical rate is probably the most discussed coning parameter [6]. The analytical approach establishes the correlations based on the equilibrium conditions of gravity forces and pressure gradients [7]. Also, Emara [8] added that in this approach, the critical rate is calculated by allowing the gravity forces equal the viscous forces in the proposed oil potential function. On the other hand, the empirical approach involves the use of laboratory experiments or computer simulation runs to obtain data that are used to develop the correlations for coning prediction. Presently, there has been a shift from the laboratory experiments approach of developing the empirical correlations to computer simulation because of the complexity of reservoirs engineering problems, and the modern advances in computer technology [9]. It is interesting to note that most of the water coning studies in vertical wells is either analytical or experimental.

In vertical wells, there are cases where the bottom water is observed in a relatively short time at the wellbore after the wells have been put on production [10]. Once the water breaks into the wells, there is rapid increase in water-oil ratio that leads to low hydrocarbon recovery. Eventually, the negative impact on the economics of the petroleum reservoir production cause for concern [11]. Water coning phenomenon in vertical wells has been studied extensively by researchers. Numerous authors have investigated the flow mechanisms in reservoir and developed correlations to estimate coning parameters: critical rate, breakthrough time and water-cut performance after breakthrough for vertical wells. Authors like Muskat and Wyckoff [12], Meyer and Garder [13], Chierici et al. [14], Wheatley [15], Chaperon [16], Abbas and Bass [17], Hoyland et al. [18], Guo and Lee [19], among others, have presented critical rate correlations for vertical wells. For breakthrough time, Sobocinki and Cornelius [20], Bournazel and Jeanson [21], Recham et al. [22] and others, have established the correlations. Then, Kuo and DesBrisay [23], Yang and Wattenbarger [24], Zamonsky et al. [25], etc. have developed correlations to evaluate postwater (water-cut) performance after breakthrough in vertical wells. Regrettably, significant variations exist in the results of the numerous water coning prediction correlations. These variations arise mainly due to the approximating assumptions used to simplify the complex mathematical solutions of the two- or three-phase flow in porous media [26]. Therefore, this paper critically evaluates the various water coning correlations for vertical wells to establish the most reliable correlation (s) for the prediction of this production ratesensitive phenomenon during oil production from bottomwater reservoirs.

\section{Water Coning Phenomenon in Vertical Wells}

In bottom-water drive reservoir, during the production of oil and gas, the flow of oil from the reservoir to the well introduces an upward dynamic force upon the fluids [27]. This dynamic (viscous) force due to wellbore pressure drawdown causes the bottom water to rise to a certain point at which the dynamic force is balanced by the height of the water beneath that point. Then, as the distance from the wellbore increases the pressure drawdown and the upward viscous force caused by it decreases. This development causes the water-oil contact (WOC) below the oil completion interval to rise toward the perforation; as depicted in Figure 1. At low production rate, a stable cone is experienced as the dynamic force offset the gravity contrast between the oil and water phase [7]. This implies that the upward dynamic force is sufficiently balanced by the weight of water beneath the cone. However, when the production rate increases, the cone height above the water oil contact (WOC) also increases. Over time, the gravity contrast between the water and oil cannot offset their mobility differences, then, the water cone becomes unstable and rises towards the well completion interval. Thus, the breakthrough (i.e., water enters the well perforation interval) occurs when the cone shaped profile becomes unstable due to the highpressure drawdown around the wellbore.

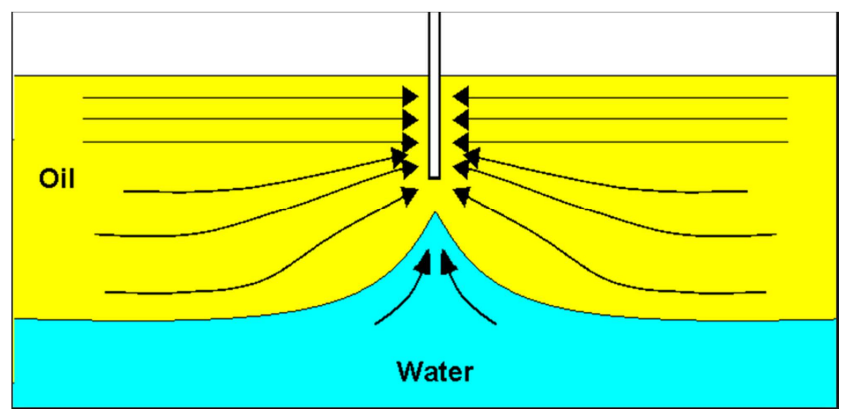

Figure 1. Water Coning in Vertical Well [28].

The main reasons for coning; especially in bottom-water drive reservoirs, is pressure drawdown. Vertical wells exhibit a large pressure drawdown in the wellbore vicinity than horizontal wells. Horizontal well technology in some cases may be a coning attenuation approach. The pioneer studies, Muskat and Wyckoff [12] and Muskat [29] observed that coning is a rate-sensitive phenomenon, which develops only after certain equilibrium conditions in the wellbore-reservoir vicinity are unbalanced by increasing the pressure differential beyond critical limits. Afterwards, intensive studies have been carried out to understand the phenomenon and several mathematical models; as expanded in Tables A1 through A3 were developed to predict water coning tendency. However, there are variations in the developed coning prediction correlations due to the assumptions regarding: reservoir types, reservoir parameters and flow types, and the model used in the correlations development. In analytical approach, water coning movement in the reservoir-wellbore vicinity is established based 
on hodograph or Dupuit-Forchhiemer's approximation model.

a. Critical Rate

During production of oil, critical rate is the rate beyond which the flowing pressure gradient at the well causes water to cone into the well through the production interval. It simply means the maximum production rate of oil without simultaneous production of water. One of the assumptions in critical rate correlations development is that the water cone has risen to a certain height before it breakthrough into the well. Theoretically, the basic coning equation for a water-oil system can be developed by applying the conservation of mass to each of the phases relating flow velocities with pressure by Darcy's law, and relating pressure across wateroil contact interfaces by capillary pressure [30]. However, this analysis states nothing directly about the time it takes the water cone to rise to the initial breakthrough position. Nevertheless, a lot of critical rate correlations have been developed in the literature for vertical wells. Some of these developed critical rate correlations for vertical wells are presented in Table A1 for the evaluation.

\section{b. Breakthrough Time}

Practically, producing oil within or below the critical rate is not economical, due to economic necessity. Therefore, operating companies often produce at a rate higher than the critical coning rate. As earlier mentioned, a stable cone exists for a limited period. Once the production rate exceeds the critical rate, the water cone moves toward the well and subsequently breaks into the wellbore. At this production stage, knowing the breakthrough time helps to improve well management and extend well life without water production [31]. Also, by estimating the breakthrough time one can optimize the production plan to maximize the delay of water or gas breakthrough time [32]. Numerous attentions have been put in by researchers to develop models to predict coning breakthrough time in vertical wells. Empirically, Sobocinski and Cornelius [20] and Bournazel and Jeanson [21] established this correlation while other authors used either analytical or numerical approach to develop the correlation for vertical wells. Some of the developed correlations to predict breakthrough time in vertical wells are presented in Tables A2 for the evaluation.

\section{c. Water-cut Performance after Breakthrough}

Aside from predicting critical rate and breakthrough time, the knowledge of the well performance in terms of water-cut or water-oil ratio (WOR) after breakthrough is important.
This prediction enables the reservoir engineer to plan the future production of the reservoir to achieve optimum oil recovery. Secondly, the prediction further evaluate the expected abandonment time of the reservoir. Kuo and DesBrisay [23] and Zamonsky et al. [25] developed correlations for water-cut (WC) performance prediction while Yang and Wattenbarger [24] presented correlation to evaluate water-oil ratio (WOR) performance after breakthrough for vertical wells. However, the obtained wateroil (WOR) based on Yang and Wattenbarger [24] correlation can be converted to water-cut using the expanded equation 1 . These developed water-cut and water-oil correlations for vertical wells are presented in Table A3.

$$
W C=\frac{W O R}{1+W O R}
$$

Furthermore, locating the completion interval to avert coning and achieve maximum oil recovery (production) has received research interest. Normally, operating companies produce from the center of the pay zone to maximize oil recovery in case of reservoirs overlaid by gas zone and underlaid by water zone. For reservoirs underlaid by strong water zone only, the completion interval is placed at the top of the reservoir. Therefore, it is pertinent to determine this location (position) in the reservoir to circumvent water coning and achieve optimum oil production. In this connection, some correlations by Guo and Lee [19], Tabatabaei et al. [33] and others have been developed to predict optimum well placement in vertical wells.

\section{Water Coning Correlations Evaluation}

Water coning in bottom-water drive reservoir is an integral part of the oil production process. Therefore, proper prediction and planning of this production rate-sensitive phenomenon must be projected and captured in the production scheme to achieve maximum oil production and/or recovery from the reservoir. To evaluate the potentials of the various water coning correlations' prediction in vertical wells, the basic reservoir and fluid properties data were extracted from the work of Khalili [32] and Kumar et al. [34]. These extracted data as presented in Table 1 were used to evaluate the various water coning correlations presented in Tables A1 through A3.

Table 1. Basic Reservoir and Fluid Properties.

\begin{tabular}{|c|c|c|c|}
\hline \multicolumn{2}{|l|}{ Reservoir data } & \multicolumn{2}{|l|}{ Fluid data } \\
\hline Pay zone thickness, h (ft) & 70 & Density of water, $\rho_{\mathrm{w}}\left(\mathrm{lb} / \mathrm{ft}^{3}\right)$ & 62.40 \\
\hline Horizontal permeability, $\mathrm{k}_{\mathrm{h}}$ (md) & 100 & Density of oil, $\rho_{\mathrm{o}}\left(\mathrm{lb} / \mathrm{ft}^{3}\right)$ & 43.67 \\
\hline Vertical permeability, $\mathrm{k}_{\mathrm{v}}(\mathrm{md})$ & 10 & Oil viscosity, $\mu_{\mathrm{o}}(\mathrm{cp})$ & 0.7 \\
\hline Drainage radius, $r_{e}(\mathrm{ft})$ & 2000 & Water viscosity, $\mu_{\mathrm{w}}(\mathrm{cp})$ & 1.0 \\
\hline Wellbore radius, $r_{w}(\mathrm{ft})$ & 0.25 & Oil formation volume factor, $B_{o}$ & 1.10 \\
\hline Formation porosity, $\varphi$ & 0.32 & Water formation volume factor, $\mathrm{B}_{\mathrm{w}}$ & 1.00 \\
\hline Average reservoir pressure, $\mathrm{P}$ (psi) & 3769 & end-point oil relative permeability $\left(\mathrm{k}_{\mathrm{ro}}\right)$ & 0.72 \\
\hline & & Connate water saturation, $\mathrm{S}_{\mathrm{wc}}$ & 0.25 \\
\hline
\end{tabular}

Source: Khalili [32] and Kumar et al. [34]. 


\section{Results and Discussion of the Evaluation}

\subsection{Critical Rate}

Figures 2 and 3 show the critical rate $\left(\mathrm{q}_{\mathrm{c}}\right)$ predictions of the various water coning correlations at different fractional well penetration $\left(h_{p} / h\right)$ in vertical well. In Figure 2, the critical rate fractional well penetration prediction indicates that Meyer and Garder [13], Chaney et al. [35], Schols [36], Hoyland et al. [18] and Ozkah and Raghavan [37] correlations' prediction have the same trend. However, the correlations predicted different values of critical rate at the same fractional well penetration; as observed. Chaperon [16] correlation predicted the highest critical rate of about $68 \mathrm{stb} / \mathrm{d}$ at a low penetration. However, this prediction trend is different from the earlier mentioned authors' prediction trend; as indicated in Figure 2. In addition, Abbas and Bass [17], Guo and Lee [19] and Tabatabaei et al. [33] predictions have about the same critical rate - fractional well penetration trend; as shown in Figure 3. However, Abbas and Bass [17] and Tabatabaei et al. [33] have a very close predictions value of critical rate - fractional well penetration relationship. As observed in Figure 3, these correlations' prediction indicate that the highest critical rate was obtained when the fractional well penetration is about 43\% for Abbas and Bass [17] and Tabatabaei et al. [33], and about $33 \%$ for Guo and Lee [19]. Therefore, the difference in the prediction of the critical rate - fractional well penetration by the various correlations are attributed to the approach and assumptions used by the authors to establish the water coning critical rate correlation in vertical wells.

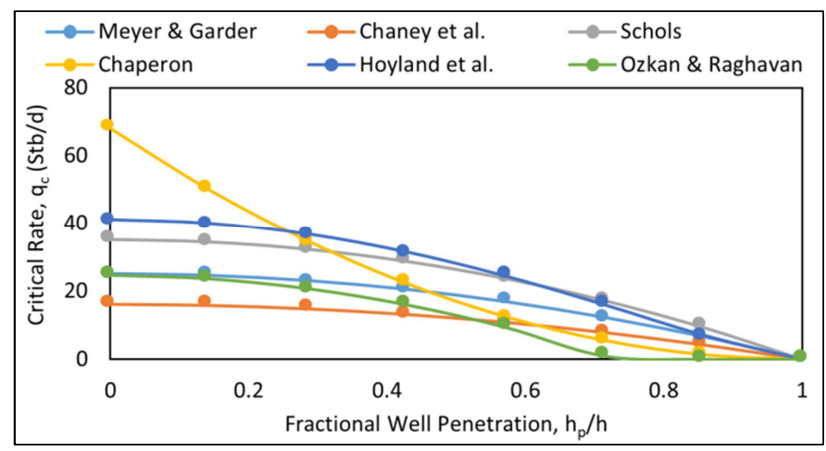

Figure 2. Critical Rate vs. Fractional Well Penetration.

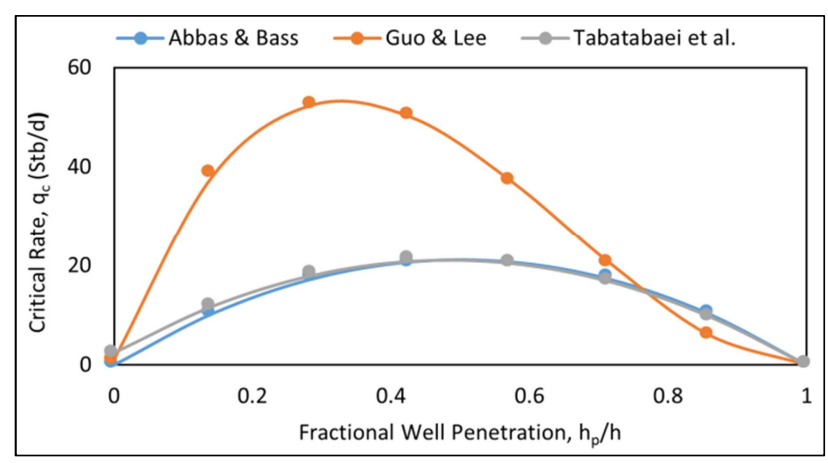

Figure 3. Critical Rate vs. Fractional Well Penetration.

\subsection{Breakthrough Time}

According to Karami et al. [11] planning to avoid and/or separate the water produced during water coning takes a long time. To this end, several correlations have been developed to predict the breakthrough time of water in vertical wells in the literature. In this study, the breakthrough time was evaluated as a function of fractional well penetration $\left(h_{p} / h\right)$. The results of this evaluation are presented in Figure 4. In this Figure, Sobocinski and Cornelius [20], Bournazel and Jeanson [21], and Yang and Wattenbarger [24] correlations show the same breakthrough time - fractional well penetration profile. While Recham et al. [22] and Permadi [38] correlations depict a close profile. It is noted that high breakthrough time $\left(t_{b t}\right)$ was obtained at low fractional well penetration for Sobocinski and Cornelius [20], Bournazel and Jeanson [21], and Yang and Wattenbarger [24] correlations' prediction. Thus, the breakthrough time decrease as the fractional well penetration increase. This is because the perforation interval is closer to the water-oil contact (WOC) when the fractional well penetration value is higher. Hence, the tendency of the vertical well to experience early breakthrough is inevitable. Additionally, the predictions of Recham et al. [22] and Permadi [38] correlations resulted in very low breakthrough time when compared to other correlations' prediction in Figure 4. The low breakthrough time as predicted by these correlations is attributed to the approach (numerical simulation and regression analysis) and assumption (s) used to develop them.

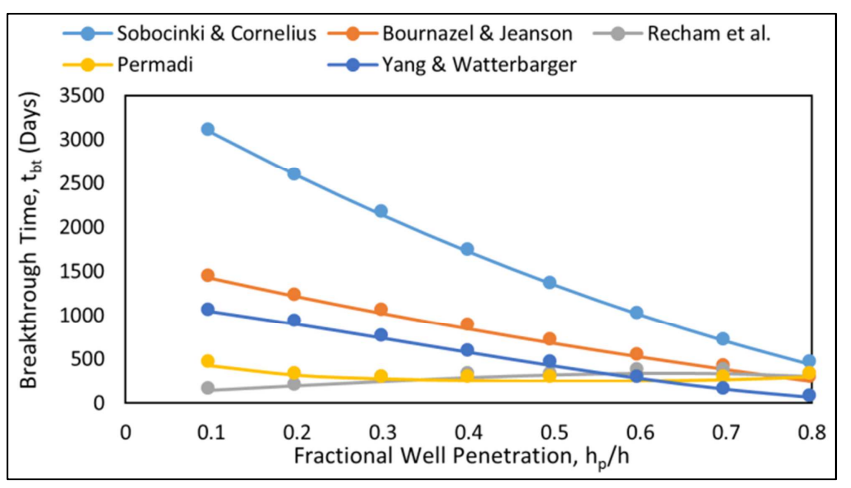

Figure 4. Breakthrough Time vs. Fractional Well Penetration.

\subsection{Water-Cut After Performance Breakthrough}

Currently, there is no analytical solution (approach) in the literature to estimate water-cut performance after breakthrough in both vertical wells. The available correlations for post-water (i.e., water-cut) breakthrough performance prediction in vertical wells are developed based on numerical simulation results. Figure 4 presents the evaluated water-cut performance after breakthrough predictions for vertical well. In the Figure, Yang and Wattenbarger [24] and Zamonsky et al. [25] correlations have the same breakthrough period but different water-cut 
performance profile. As observed, Yang and Wattenbarger's correlation predicted less water-cut of about 0.3 after 8.5 years. The reason for this prediction may be attributed to the fact that this correlation was developed based on water-oil ratio (WOR); which was converted to water-cut using the expanded Equation 1. Conversely, Kuo and DesBrisay [23] and Zamonsky et al. [25] correlations' predicted different breakthrough period and the same water-cut performance profile in vertical wells; as depicted in Figure 5.

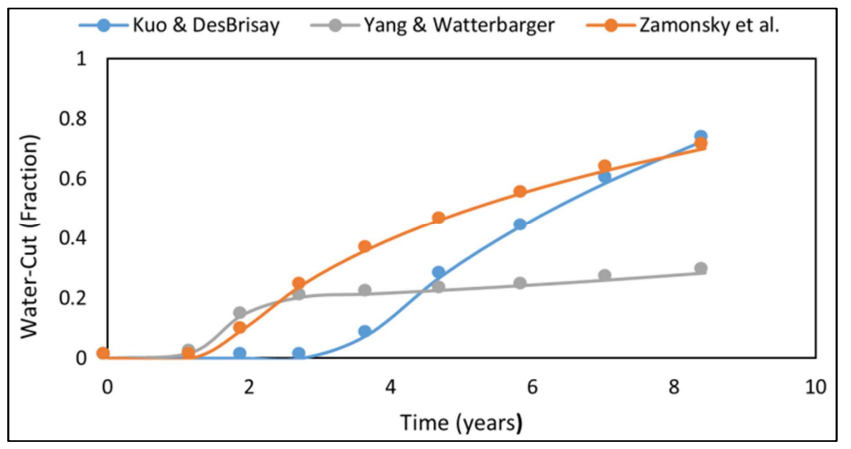

Figure 5. Water-cut Performance after Breakthrough vs. Time (Vertical Well).

\subsection{Learnings from the Water Coning Correlations Evaluation}

The evaluation of the various water coning correlations in vertical wells have put forward the reliability of these correlations available in the literature. Therefore, it is pertinent to note that the approaches: analytical, empirical, numerical or combined as well as the assumption (s) are the major factors that affect the reliability of the various water coning correlation predictions. Hence, most of the various water coning correlations evaluated in this study predicted different values for the water coning parameters: critical rate, breakthrough time and water-cut performance after breakthrough. However, despite the difference in their predictions, some of the correlations have about the same profile for the water coning parameters. Furthermore, the critical rate $\left(\mathrm{q}_{\mathrm{c}}\right)$ is indirectly dependent on fractional well penetration $\left(h_{p} / h\right)$; as low fractional well penetration $\left(h_{p} / h\right)$ gives high critical rate $\left(\mathrm{q}_{\mathrm{c}}\right)$. Additionally, most correlations indicate that breakthrough time $\left(\mathrm{t}_{\mathrm{bt}}\right)$ is also indirectly dependent on the fractional well penetration $\left(h_{p} / h\right)$. This evaluation further shows that correlations developed from water-cut data for the prediction of post-water behaviour after breakthrough exhibit more realistic predictions in watercut profile than the correlations developed from water-oil ratio.

\section{Conclusion}

In bottom water-drive reservoir, oil production strategy to overcome the early coning of water into the production interval requires the knowledge of the critical oil rate - water free oil production rate. Thus, several correlations to predict this production rate as well as the time it takes the water to cone into the well (i.e., breakthrough time) have been developed by authors based on numerous approaches and assumptions. Furthermore, correlations to predict the performance of the water-cut after breakthrough were developed. However, limited literatures have evaluated the consistency of these water coning correlations to predict coning parameters in vertical wells. Therefore, this study critically evaluates water coning correlations in vertical wells, and the following conclusions are drawn:

i. most correlations prediction for water coning parameters have the same profile, but almost all the correlations predicted different values for the water coning parameters;

ii. critical production rate and breakthrough time are indirectly dependent on the fractional well penetration in vertical wells; and

iii. correlations to evaluate post-water behaviour or water-cut performance after breakthrough developed from water-cut data predicts more proficient watercut profile than correlations from water-oil ratio data.

Therefore, in bottom-water reservoirs with active aquifer, proper planning and completion of the well (s) in vertical direction will require the consideration of fractional well penetration to achieve optimum critical oil production rate and breakthrough time.

\section{Nomenclature}

$q_{c}=$ critical rate, $s t b / d$

$\Delta \rho=$ water-oil density difference, $l b / f t^{3}$

$\mu_{o}=$ oil viscosity, $c p$

$\mu_{w}=$ water viscosity, $c p$

$r_{w}=$ wellbore radius, $f t$

$r_{e}=$ drainage radius, $f t$

$r_{w e}=$ effective wellbore radius, $f t$

$r_{e h}=$ horizontal well drainage radius, $f t$

$h$ = pay-zone thickness, $f t$

$A=$ reservoir area, $f t^{2}$

$h_{p}=$ height of completion interval, $f t$

$k_{v}=$ vertical permeability, $m d$

$k_{h}=$ horizontal permeability, $m d$

$k_{r o}=$ oil relative permeability at $S_{w c}$

$t_{b t}=$ breakthrough time, days

$B_{o}=$ oil formation volume factor, $r b / s t b$

$B_{w}=$ water formation volume factor, $r b / s t b$

$M=$ mobility ratio

$g$ = gravity constant, $\mathrm{ft} / \mathrm{hr^{2 }}$

$\varphi=$ formation porosity, fraction

$\alpha=$ mobility ratio exponent

$h_{a p}=$ height above perforation, $f t$ 
$h_{b p}=$ height below perforation, $f t$

$h_{w b}=$ breakthrough height (cone height), $f t$

$h_{w}=$ water zone thickness, $f t$

$q_{o}=$ oil production rate $s t b / d$

$q_{c_{D}}=$ dimensionless critical rate

$\lambda_{o}=$ end-point oil mobility, $\mathrm{Pa} / \mathrm{s}$

$r_{e D}=$ dimensionless drainage radius

$Z_{D}=$ dimensionless cone height
$\left(t_{D}\right)_{b t}=$ dimensionless breakthrough time

$S_{w c}=$ connate water saturation

$S_{o r}=$ residual oil saturation

$\Delta P_{v}=$ pressure drawdown due to viscous effects, $p s i$

$\Delta \gamma=$ difference between hydrostatic gradients of water and oil, psi/ft

$W C=$ water-cut

$W C_{D}=$ dimensionless water-cut

$W O R=$ water-oil ratio

\section{Appendix}

\section{Appendix $A$}

Table A1. Correlations for Water Coning Critical Rate Prediction.

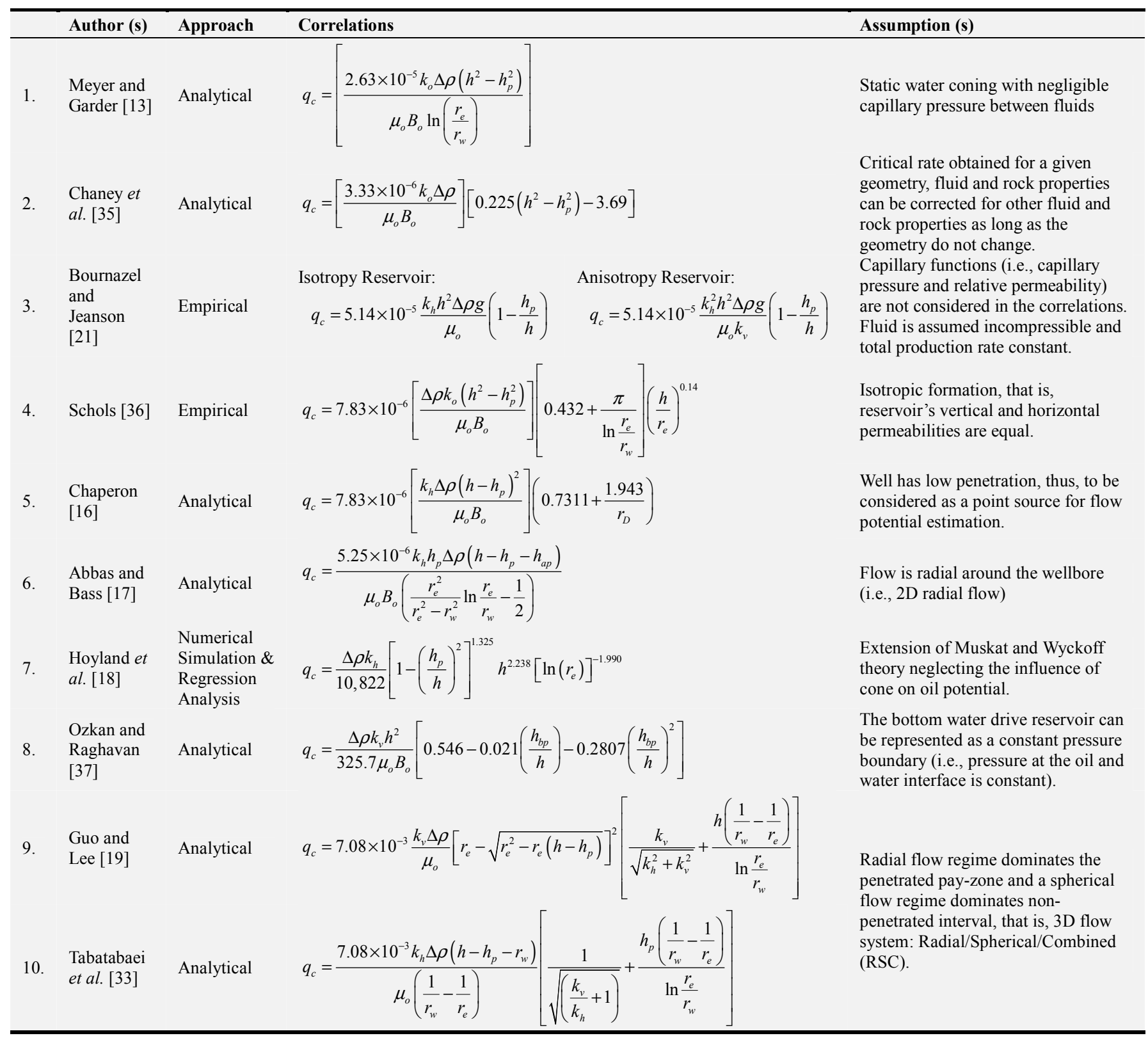


Table A2. Correlations for Water Coning Breakthrough Time Prediction.

\begin{tabular}{|c|c|c|c|c|}
\hline & Author (s) & Approach & Correlations & Assumption (s) \\
\hline 1. & $\begin{array}{l}\text { Sobocinki and } \\
\text { Cornelius [20] }\end{array}$ & Empirical & $\begin{array}{l}t_{b t}=7.30 \times 10^{2} \frac{\mu_{o} \varphi h F_{k}}{\Delta \rho k_{h}\left(1+M^{\alpha}\right)}\left(t_{D}\right)_{b t} \text { Where; }\left(t_{D}\right)_{b t}=\frac{Z_{D}}{4}\left(\frac{16+7 Z_{D}-3 Z_{D}^{2}}{7-2 Z_{D}}\right) \alpha= \\
0.5 \text { for } \mathrm{M}<1 ; 0.6 \text { for } 1<\mathrm{M} \leq 10\end{array}$ & $\begin{array}{l}\text { Used single sand packed laboratory } \\
\text { model with water-oil system for the } \\
\text { experimental work. }\end{array}$ \\
\hline 2. & $\begin{array}{l}\text { Bournazel and } \\
\text { Jeanson [21] }\end{array}$ & Empirical & $\begin{array}{l}t_{b t}=7.30 \times 10^{2} \frac{\mu_{o} \varphi h F_{k}}{\Delta \rho k_{h}\left(1+M^{\alpha}\right)}\left(t_{D}\right)_{b t} \text { Where; }\left(t_{D}\right)_{b t}=\frac{Z_{D}}{3-0.7 Z_{D}} \alpha=0.7 \text { when } \\
0.14<\mathrm{M} \leq 7.3\end{array}$ & $\begin{array}{l}\text { Capillary functions (i.e., capillary } \\
\text { pressure and relative permeability) } \\
\text { are not considered in the } \\
\text { correlations. Fluid is assumed } \\
\text { incompressible and total } \\
\text { production rate constant. }\end{array}$ \\
\hline 3. & $\begin{array}{l}\text { Yang and } \\
\text { Wattenbarger } \\
{[24]}\end{array}$ & Analytical & $t_{b t}=\frac{\varphi A\left(1-S_{w c}-S_{o r}\right)\left[h-h_{w b}-h_{a p}-h_{p}\right.}{q}$ & $\begin{array}{l}\text { Based on the work of Addington } \\
\text { (1981); assuming that water is } \\
\text { displacing oil in a piston-like } \\
\text { manner. }\end{array}$ \\
\hline 4. & $\begin{array}{l}\text { Recham et al. } \\
\text { [22] }\end{array}$ & $\begin{array}{l}\text { Numerical } \\
\text { Simulation \& } \\
\text { Regression } \\
\text { Analysis }\end{array}$ & $\begin{array}{l}t_{b t}=2996(1+M)^{0.64}\left(\frac{1}{r_{e D}}\right)^{1.11}\left(\frac{1}{q_{D}}\right)^{0.68}\left(1-\frac{h_{p}}{h_{o}}\right)^{0.65}\left(1-\frac{h_{b p}}{h_{o}}\right)^{1.4}\left(1-\frac{h_{a p}}{h_{o}}\right)^{0.99} \text { where; } \\
q_{D}=\frac{651.4 \mu_{o} B_{o} q_{o}}{\Delta \rho h_{o}^{2} k_{h}} ; r_{e D}=\frac{r_{e}}{h_{o}} \sqrt{\frac{k_{v}}{k_{h}}} ; M=\frac{\mu_{o} k_{r w}}{\mu_{w} k_{r o}}\end{array}$ & $\begin{array}{l}\text { For the modelled reservoir, 3D } \\
\text { radial model for water coning } \\
\text { vertical well and 3D irregular } \\
\text { Cartesian model for water cresting } \\
\text { (coning) in horizontal well. }\end{array}$ \\
\hline 5. & Permadi [38] & $\begin{array}{l}\text { Numerical } \\
\text { Simulation \& } \\
\text { Regression } \\
\text { Analysis }\end{array}$ & $t_{b t}=5.3 \times 10^{-2}\left[\frac{\varphi^{1.021} \mu_{w}^{0.511} r_{e}^{0.424} k_{h}^{0.745} h^{3.057}(\Delta \rho)^{0.124}}{\mu_{o}^{0.615} q_{o}^{0.962} k_{v}^{0.859} h_{p}^{0.497} h_{a p}^{0.455}}\right]$ & $\begin{array}{l}\text { Used } 2 \text { D homogeneous radial } \\
\text { model with anisotropy properties. } \\
\text { The bottom water influx was } \\
\text { modelled using Carter-Tracy } \\
\text { aquifer formulation. }\end{array}$ \\
\hline
\end{tabular}

Table A3. Correlations for Water-cut Performance after Breakthrough Prediction

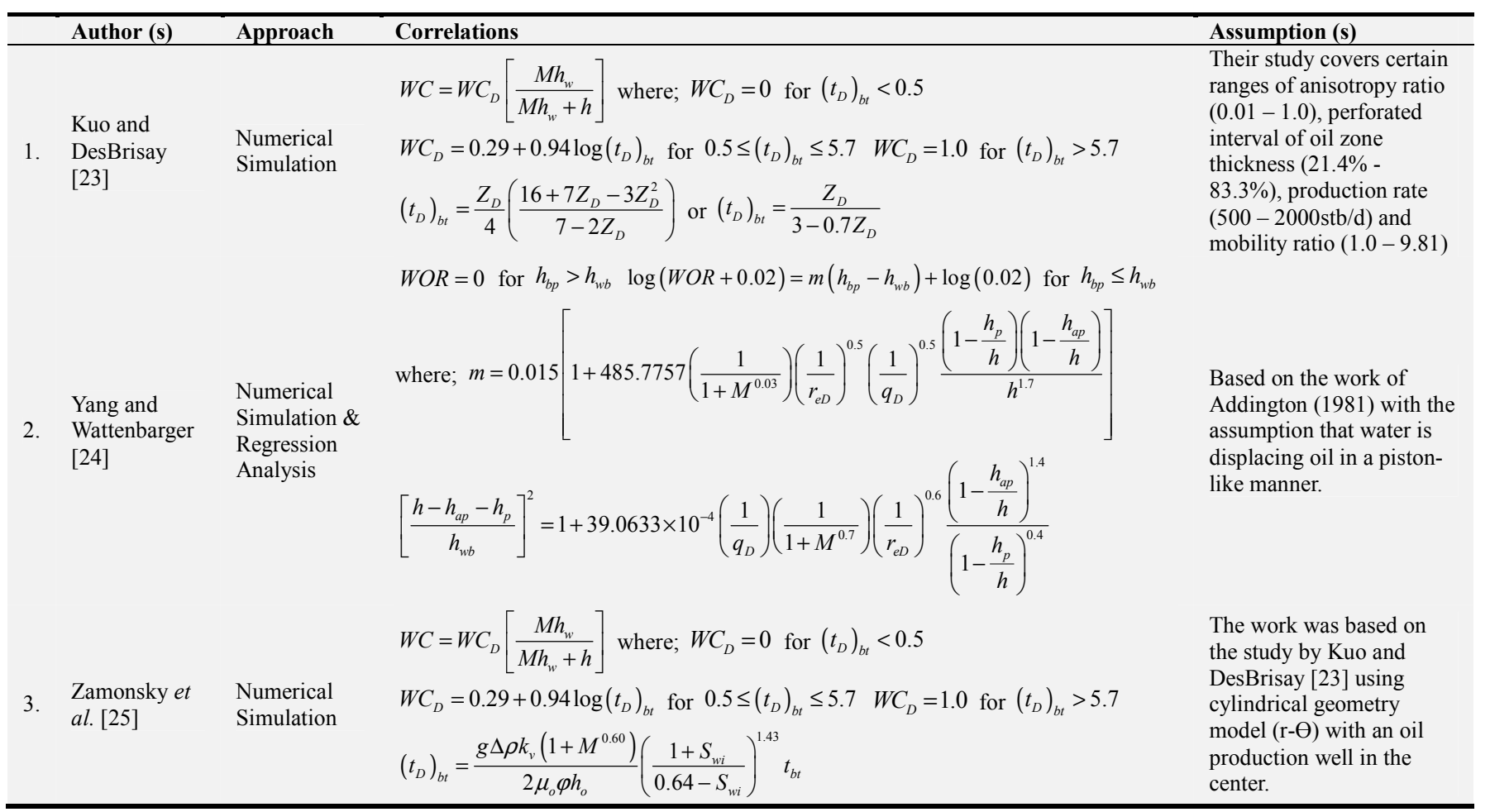

[3] www.petrowiki.org/Water_and_gas_coning. Accessed $10^{\text {th }}$ May, 2017.

\section{References}

[1] Ayeni, K. B. (2008). Empirical Modeling and Simulation of Edgewater Cusping and Coning. PhD. Dissertation submitted to Graduate Studies of Texas A\&M University, USA.

[2] Okwananke, A. and Isehunwa, S. (2008). Analysis of Water Cresting in Horizontal Wells. Society of Petroleum Engineers, SPE Paper 119733.
[4] Azim, R. A. (2016). Evaluation of Water Coning Phenomenon in Naturally Fractured Oil Reservoirs. Journal of Petroleum Exploration, Production and Technology, Vol. 6, pp. 279-291.

[5] Hatzignatiou, D. G. and Mohamed, F. (1994). Water and Gas Coning in Horizontal and Vertical Well. Paper presented at the $45^{\text {th }}$ Annual Technical meeting of the Petroleum Society of Canadian Institute of Mining held in Calgary, Canada, 12-15 June. 
[6] Osisanya, S. O., Recham, R. and Touami, M. (2000). Effects of Water Coning on the Performance of Vertical and Horizontal Wells - A Reservoir Simulation Study of Hassi R' Mel Field, Algeria. Paper presented at Canadian International Petroleum Conference held at Calgary, Alberta, Canada, 4-8 June.

[7] Okon, A. N., Appah, D. and Akpabio, J. U. (2017). Water Coning Prediction Review and Control: Developing an Integrated Approach. Journal of Scientific Research and Reports, Vol. 14, No. 4, pp. 1-24.

[8] Emara, R. (2016). Water Coning in Horizontal Wells. International Advanced Research in Science, Engineering and Technology, Vol. 3, No. 12, pp. 24-31.

[9] Recham, R. (2001). Super-Critical Rate Based on Economics Recovery in Water and Gas Coning by using Vertical and Horizontal Well Performance. Paper presented at Society of Petroleum Engineers Offshore Europe Conference held in Aberdeen, Scotland, 4-7 September.

[10] Permadi, P., Lee, R. L. and Kartoamodjo, R. S. T. (1995). Behaviour of Water Cresting under Horizontal Wells. Paper presented at Society of Petroleum Engineers Annual Technical Conference and Exhibition held in Dallas, Texas, 22-25 October.

[11] Karami, M., Manshad, A. K. and Ashoori, S. (2014). The Prediction of Water Breakthrough Time and Critical Rate with a New Equation for an Iranian Oil Field. Journal of Petroleum Science and Technology, Vol. 32, No. 2, pp. 211-216.

[12] Muskat, M. and Wyckoff, R. D. (1935). An Approximate Theory of Water Coning in Oil Production. Petroleum Development and Technology in Transactions of American Institute of Mining and Metallurgical Engineers, Vol. 114, pp. 144-163.

[13] Meyer, H. I. and Garder, A, O. (1954). Mechanics of TwoImmiscble Fluid in Porous Media, Journal of Applied Physics, Vol. 25, No 11, pp. 1400-1406.

[14] Chierici, G. L., Ciucci, G. M. and Pizzi, G. (1964). A Systematic Study of Water Coning by Potentiometric Models. Journal of Petroleum Technology, Vol. 17, 923-929.

[15] Wheatley, M. J. (1985). An Approximate Theory of Oil/Water Coning. Paper presented at the 60th Annual Technical Conference and Exhibition of the Society of Petroleum Engineers held in Las Vegas, USA, 22-25 September.

[16] Chaperon, I. (1986). Theoretical Study of Coning Toward Horizontal and Vertical Wells in Anisotropic Formations: Subcritical and Critical Rates. Society of Petroleum Engineers, SPE Paper 15377.

[17] Abbas, H. H. and Bass, D. M. (1988). The Critical Production Rate in Water-Coning Systems. Paper presented at the Society of Petroleum Engineers Permian Basin Oil and Gas Recovery Conference held in Midland, Texas, 10-11 March.

[18] Hoyland, L. A., Papatzacos, P. and Skjaeveland, S. M. (1989). Critical Rate for Water Coning: Correlation and Analytical Solution. Society of Petroleum Engineers, SPE 15855.

[19] Guo, B. and Lee, R. L. (1993). A Simple Approach to Optimization of Completion Interval in Oil/Water Coning Systems. Paper presented at the Society of Petroleum Engineers Permian Basin Oil and Gas Recovery Conference held in Midland, Texas, 18-20 March.
[20] Sobocinski, D. P. and Cornelius, A. J. (1965). A Correlation for Predicting Water Coning Time. Journal of Petroleum Technology, pp. 594-600.

[21] Bournazel, C. and Jeanson, B. (1971). Fast Water-Coning Evaluation Method. Society of Petroleum Engineers, SPE Paper 3628.

[22] Recham, R., Osisanya, S. O. and Touami, M. (2000). Effect of Water Coning on the Performance of Vertical and Horizontal Wells - A Reservoir Simulation Study of Hassi R'mel Field, Algeria. Paper presented at Society of Petroleum Engineers/Petroleum Society of Canadian Institute of Mining, Metallurgy and Petroleum International Conference on Horizontal Well Technology held in Calgary, Alberta, Canada, 6-8 November.

[23] Kuo, C. T. and DesBrisay, C. L. A. (1983). Simplified Method for Water Coning Predictions. Proceedings of the $58^{\text {th }}$ Annual Technical Conference and Exhibition of the Society of Petroleum Engineers held in San Francisco, 5-8 October.

[24] Yang, W. and Wattenberger, R. A. (1991). Water Coning Calculation for Vertical and Horizontal Wells. Paper presented at the $66^{\text {th }}$ Annual Technical Conference and Exhibition of the Society of Petroleum Engineers held in Dallas, Texas, 6-9 October.

[25] Zamonsky, G., Lacentre, P. E. and Larreteguy, A. E. (2005). Towards Better Correlations for Water Production Prediction using Sensitivity Analysis and Numerical Simulation Models. Paper presented at the Society of Petroleum Engineers Europec/EAGE Annual Conference held in Madrid, Spain, 1316 June.

[26] Inikori, S. O. (2002). Numerical Study of Water Coning Control with Downhole Water Sink (DWS) Well Completions in Vertical and Horizontal Wells. Ph. D. Dissertation Submitted to the Graduate Faculty of the Louisiana University.

[27] El-Gogary, A. F., El-Masry, H. H., Kortam, M. M. and ElRayek, H. R. (2015). Innovative Water Coning Techniques for Horizontal Wells in Isotropic Reservoirs - Successful Case History from Belayim Field. Paper presented at Society of Petroleum Engineers North Africa Technical Conference and Exhibition held in Cairo, Egypt, 14-16 September.

[28] Bekbauov, B. E., Kaltayev, A., Wojtanowicz, A. K. and Panfilov, M. (2012). Numerical Modeling of the Effect of Disproportionate Permeability Reduction Water-Shutoff Treatments on Water Coning. Journal of Energy Resources Technology, Vol. 135, No. 1, pp. 1-10.

[29] Muskat, M. (1947). The Performance of Bottom Water-Drive Reservoirs. Transactions of American Institute of Mining and Metallurgical Engineers, Vol. 170, No. 1, pp. 81-111.

[30] Mensah, E. (2011). Development of Breakthrough Time Correlations for Coning in Bottom Water Support Reservoirs. Unpublished M. Sc. Thesis submitted to Graduate Faculty, African University of Science and Technology.

[31] Wagenhofer, T. and Hatzignatiou, D. G. (1996). Optimization of Horizontal Well Placement. Paper presented at Society of Petroleum Engineers Western Regional meeting held in Anchorage, Alaska, 22-24 May.

[32] Khalili, A. (2005). A Review of Critical Coning Rate Correlations and Identifying the most Reliable Equation. M. Sc. Dissertation submitted to the School of Petroleum Engineering, University of New South Wales. 
[33] Tabatabaei, M., Ghalambor, A. and Guo, B. (2012). An Analytical Solution for Water Coning in Vertical Wells. Society of Petroleum Engineers Production and Operation, pp. 195-204.

[34] Kumar, M., Sharma, P. and Gupta, D. K. (2017) Sensitivity Study of Horizontal Length, Offset from Water Oil Contact and Withdrawal Rate of Horizontal Well in Bottom Water Drive Reservoir. Journal of Petroleum Exploration, Production and Technology. doi.10.1007/s13202-0170348-9.

[35] Chaney, P. E., Noble, M. D., Henson, W. L. and Rice, T. D. (1956). How to Perforate your Well to Prevent Water Coning. Oil and Gas Journal, pp. 108-114.
[36] Schols, R. S. (1972). Water Coning - An Empirical Formula for the Critical Oil-Production Rate. Erdoel - Erdgas Zeitschrift, Vol. 88, No. 1, pp. 6-11.

[37] Ozkan, E. and Raghavan, R. A. (1990). A Breakthrough Time Correlation for Coning toward Horizontal Wells. Paper presented at Society of Petroleum Engineers Europeans Conference held in The Hague, Netherlands, 22-24 October.

[38] Permadi, A. K. (2009). New Empirical Correlation for Predicting Water Breakthrough Time of a Vertical Well in a Bottom-Water Reservoir. Jurnal Teknologi Mineral. https://petroleumstudies.files.wordpress.com/2009/03/11.pdf. Accessed 10 $0^{\text {th }}$ May, 2017. 